\title{
Teknolojik Determinizm Çerçevesinde Türkiye'de Web Dizilerinin Toplumsal Dönüşüme Etkileri: Fi Dizisi Örneği
}

\author{
Ali Murat KIRIK ${ }^{1}$ ve Nilüfer BAȘTAȘ-BAKIȘ²
}

Öz

Televizyon, yayınladığı çeşitli programlarla dünyanın neredeyse her yerinden ilgiyle izlenmektedir. Özellikle dizi ve filmlere olan ilgi televizyon izleme oranlarının artmasında çok etkilidir. Yeni medya ile beraber gelişim gösteren internet teknolojisi günümüzde aranan her şeyin adresi konumuna dönüşmüştür. İnsanlar artık istediği her içeriği, istediği zaman internette bulabilmektedir. Televizyon bu açıdan biraz daha kısıtlı olmakla beraber, zamanla yerini internete bırakmaktadır. Bașta Z kuşağ1 olmak üzere ardından Y kuşağ1 günümüzde internet teknolojisini aktif olarak kullanmaktadır. Y ve Z kuşağ1 kadar olmasa da X kuşağı da internete entegre olmaya çalışmakta fakat tamamıyla geleneksel medyadan kopamamaktadır. Bu durum geleneksel medyanın varlığını hala sürdürebilmesini sağlamaktadır. Bu kadar yaygın olarak kullanılan internet, günümüzde içine en çok tercih edilen program türü olan web dizilerini de alarak televizyonu bir adım daha geri de bırakmıştır. Teknolojinin gelişiminin bu denli her alana yansıması akıllara Marshall McLuhan'ın öncülük ettiği teknolojik determinizm kavramını getirmektedir. Kültürü etkisi altına alan dizi ve filmler, günümüzde toplumu yönlendiren önemli türlerdir. Teknolojinin gelişimini yakından takip eden web dizileri, izleyicilere bu durumu yansıtmaktadır. Ancak bu durumun insanları iyi yönde mi yoksa kötü yönde mi etkilediği tartışma konusudur. Bu çalıșmada, teknolojik öğeleri yoğun bir şekilde barındıran web dizilerinin toplumu ne ölçüde etkilediği tartışılmaktadır. Çalışmada Fi isimli web dizisi Marshall McLuhan'in teknolojik determinizm teorisi bağlamında içerik analizi gerçekleştirilerek incelenmiştir.

Anabtar Kelimeler: Internet, Web dizileri, Teknoloji, Teknolojik determinizm, Teknolojik iyimserlik, Teknolojik kötümserlik, Teknolojinin sosyal inşası

Within the Framework of Technological Determinism the Effects of Web Series to Social Transformation in Turkey: The Case of Fi Web Series

\begin{abstract}
Television is being watched with interest from almost all parts of the world with various programs it broadcasts. Particularly, interest in series and films is very effective in increasing television viewing rates. Internet technology has evolved with new media and has become the address of everything that is wanted today. People can now find any content they want on the Internet at any time. Television is a little more limited in this point, but it leaves its place to the internet in time. The $\mathrm{Z}$ generation, followed by the $\mathrm{Y}$ generation, uses the internet technology actively. Even though not as much as the $\mathrm{Y}$ and $\mathrm{Z}$ generation also the $\mathrm{X}$ generation is trying to integrate with the internet, but it cannot be completely separated from the traditional media. This situation allows traditional media to continue to exist. So widespread used internet, nowadays, because the internet series are watched very much, it left the television a step back. The reflection of the development of technology in every field brings to mind the concept of technological determinism develop pioneered by Marshall McLuhan. The series and films that influence the culture are important genres that direct society today. Following the development of the technology, the internet series brings to mind the question of whether media technologies affect people in a good or bad way with every content they publish and how does it convey and reach these effects to the audience? In our study, it is discussed that what extent the internet technology, which contains the technological elements in an intensive way, affects the society with the web series published by them. It will be analysed with optimistic, pestimistic and social Construction of Technology - SCOT) point of view. Marshall McLuhan's theory of technological determinism constitutes the theory of the study. The method of research, content analysis also the sample is Fi web series.
\end{abstract}

Key Words: Internet, Web series, Technology, Technological determinism, Technological optimisim, Technological pessimisim, Social construction of technology

\section{Atıf İçin / Please Cite As:}

Kırık, A. M. ve Baştaş-Bakış, N. (2020). Teknolojik determinizm çerçevesinde Türkiye'de web dizilerinin toplumsal dönüşüme etkileri: Fi dizisi örneği. Manas Sosyal Arastırmalar Dergisi, 9(3), 1820-1835.

Geliş Tarihi / Received Date: 13.06.2019

Kabul Tarihi / Accepted Date: 13.11.2019

\footnotetext{
${ }^{1}$ Doç. Dr. - Türkiye Marmara Üniversitesi İletişim Fakültesi, murat.kirik@marmara.edu.tr - ORCID: 0000-0001-5712-9401

2 Türkiye Marmara Üniversitesi Sosyal Bilimler Enstitüsü, niluferbastas47@gmail.com - ORCID: 0000-0001-7379-3468
} 


\section{Giriş}

İletişim ve teknoloji birbiriyle sürekli etkileşim halinde olup, günümüzde bu iki kavram iç içe geçmiştir. İletişim, varlı̆̆ını teknolojik gelişmelerle birlikte her geçen gün yenilemektedir. Kişiler yaşamlarının devamı için iletişim yoluyla evreni ve birbirlerini anlamlandırmaktadır. İletişimin bu vazgeçilmez yönü teknoloji ile bir araya geldiğinde sosyal hayat değişim göstermektedir.

Bugün, iletişim ve bilgi çağı olarak nitelendirilmektedir. Her iki öğe de bugün varllğını sürdürse de tam anlamıyla istenen düzeye ulaşamamıştır. Uzun zamandan beri insanlığın en büyük isteklerinden biri tamamıyla bilgi çağına geçmektir. Bilgi çağının beraberinde getirmiş olduğu teknolojik gelişmeler iletişim şeklinin değişmesine sebep olmuştur. Eskiden yüz yüze olan iletişim günümüzde teknolojik icatlar ile beraber kültürel bir deformeye uğramış, bireyleri yalnızlaştırmıştır. Birey vaktinin çoğunu teknolojik cihazlara ayırmaya başlamıştır. Sanayi devrimi, bilgisayarın icadı ve internetin ortaya çıkmasıyla eğitim, sanat, sağllk, iletişim gibi neredeyse her alan değişim göstermiştir. Şüphesiz ki teknolojik gelişmelerin faydaları sayısızdır fakat zararlarının da olabileceği göz ardı edilmemesi gereken bir konudur. Bugün, insanlık kendisini teknolojik gelişmelere tamamen adamıştır. Web 3.0 ile geliştirilen robotik ve yapay zeka çalışmalarının insanlık için birer tehdit potansiyeline dönüşebilmesi olanaklıdır. Bu bağlamda teknolojik gelişmeler önü alınamaz şekilde ilerlemektedir. Marshall McLuhan'ın "bahklar, kayzya vurmadıklar sürece suyu fark etmemektedirler" (https://www.goodreads.com, Erişim Tarihi, 23.09.2018) sözü, bugün insanlığın içinde bulunduğu durumu özetlemektedir.

Birçok alanda olduğu gibi internetin bu denli teknolojik gelişmeler sayesinde ilerlemesi nitekim televizyonu da etkilemiştir. Günümüzde artık televizyondan izlenen her şey internette anında izlenebilmektedir. Bir eğlenme aracı olan televizyon dizileri tüm dünyada olduğu gibi ülkemizde de çok fazla izlenmektedir. Hatta Türk izleyici televizyon dizilerine birçok ülkeden bile daha fazla zaman ayırmaktadır. Ülkemizde son zamanlarda özellikle Y ve Z kuşağı olan gençler internetin sağlamış olduğu olanaklar sayesinde yabancı web dizilerine yönelmişlerdir. Bunun tabi ki çeşitli sebepleri bulunmaktadır. İlerleyen bölümlerde bu konu da tartısılacaktır. Türkiye'de ki medya şirketleri durumun bu şekilde ilerlemesi ve Netflix gibi büyük şirketlerin pazar paylarına ortak olmamaları için harekete geçmişlerdir. Bunun sonucunda Blu TV ve Puhu TV gibi internet televizyonları ortaya çıkmı̧tır. Böylelikle Türkiye'de internet televizyonculuğuna adım atılmıştır.

Teknolojik determinizm kavramının öncüsü olan Marshall McLuhan, bu çalışmanın kuramını oluşturmaktadır. Türk web dizilerinin durumu göz önüne alınarak, Fi web dizisi içerik analizi yöntemiyle ayrıntılı olarak açıklanacaktır.

\section{Yeni Medya ile Değişen Dizi Yayıncılı̆̆1}

Yeni medya kavramı ortaya çıkana kadar, televizyon ev ortamının en önemli kitle iletișim araçlarından biri olma özelliği taşımaktaydı. Televizyon çok uzun bir süre tek yönlü bir iletişim aracı olarak bu görevini görmüştür. Bu durum da izleyenlerin pasif bir konumda olduğunu göstermektedir. Yani izleyici, sadece mesajın alıcısı konumundadır. Durum uzun bir süre böyle devam etmiştir. 2000'li yıllarda internetin toplumsal hayatta aktif olarak kullanılmaya başlanmasıyla durum değişmiştir. Bu ağın hızlı olması kişiler arası iletişimi kolaylaştırmış, istenilen yerde ve zamanda iletişime geçebilme rahatlığını sağlamıştır. İnternet üzerinden yazıll, görüntülü ve sesli olarak istenilen zamanda sohbet edilebilmekte ve (e-posta) gönderilebilmektedir (Kırık, 2010, s. 62-63). Yaşanan teknolojik gelişmelerle dijital taşınılabilir cihazlar hayatımıza girmiştir. Bununla beraber toplumsal hayat bir dönüşüme girmiştir (Aydın, 2017, s. 430).

Özelikle dizi alanında yaygınlık gösteren bu durum, internet dizisi kavramını ortaya çıkarmıştır. Sürelerin daha kısa, konuların daha yaratıcı, sansürün daha az olması ve oyuncuların yeteneklerini gösterebilme şanslarının daha fazla olmasıyla ortaya çıkan işler de daha profesyonel olmaya başlamıştır. Bu da web dizilerinin daha özgür bir ortamda yapıldığını göstermektedir (http://www.milliyet.com.tr, Erişim Tarihi, 29.04.2018). Özellikle sansür ve reyting sorunları ile karşı karşıya olan yönetmenler ve yapımcılar çektikleri işleri artık internette yayınlamayı tercih etmektedirler. Bunun yanında amatör olan gruplar da bazı çekimler yapıp sosyal medyadan yayınlamaya başlamışlardır. İnternet bu açıdan önemli bir avantaj görevi görmektedir (https://www.fakiryazar.com, Erişim Tarihi, 29.04.2018). 


\section{Teknolojik Bir Olgu Olarak Web Dizileri}

Teknolojinin ve medyanın günümüzde insanın vazgeçilmez bir parçası olduğu aşikardır. Teknolojik gelişmelerin bir uzamı olan medya günlük hayatta kuşkusuz büyük bir önem teşkil etmektedir (Güz, 2012, s. 16). Özellikle de 1970 'lerden itibaren başlayan teknolojik gelişmeler, internetin ortaya çıkışı ve yeni medyanın gelișimi toplumsal hayatı değiștirmiștir. Bu gelișmelerle elektronik alanındaki ilerleme ve bilgisayarların başta iletişim alanında olmak üzere her alanda kullanılması iletişim alanındaki keskin çizgilerin ortadan kalkmasını sağlamıştır. Böylece farklı kitle iletişim araçları tek bir ortamda birleşerek yöndeşme kavramı ortaya çıkmıştır. Bu olgularla da radyo, televizyon ve yazılı basın gibi kitle iletişim araçları eski ya da geleneksel kitle iletişim araçları olarak insan hayatında varlığını sürdürmeye devam etmektedir (Aktaş, 2007, s. 1).

Teknolojinin gelişmesi cihazların da gelişmesini sağlamıştır. Özellikle çekimde kullanılan cihazların çeşitlenmesini sağlamışır. Cihazlar çeşitlendikçe de ucuzlamaya da başlamıştır. Eskiden kocaman olan kameralar günümüzde küçük boyutlarda piyasada yerini almaktadır. Küçük olması ile beraber yeni olan teknolojiyi de içerisinde muhafaza edebilmektedir. Bu cihazlar 4K çekimler bile yapabilmektedirler. Büyük bütçelere gerek kalmadan da ses, 1şık ve kamera cihazları alınabilmektedir. Bu sayede büyük medya şirketleri yerine birçok istekli kesim de çekim yapabilmektedir. Yeni medya ile beraber gelen sosyal medya olgusu bireylere daha özgür bir ortam yarattığ1 için çektiklerini de rahatlıkla bu platformlara para harcamadan koyabilmektedirler. Aynı zamanda sansürün, engellemenin ve yasağın daha az olması da bu alanın büyük bir fırsat olduğunu göstermektedir. Hatta yapılan işlerin beğeni alması sayesinde ekipler kendilerine sponsor bile bulabilmektedirler (https://www.fakiryazar.com, Erişim Tarihi, 29.04.2018).

Modern web toplumundaki bu değişim televizyon dizilerini de etkilemiştir. Bugün dünyanın her yerinden insanlar bilgisayarlar sayesinde izlemek istedikleri içerikleri ve dizileri sınırsız bir şekilde yeni medya sayesinde izleyebilmektedirler. Bu değişimler insanların televizyon izleme biçimini değiştirmiştir. Televizyon dizilerinin haftada bir yayınlanması izleyiciyi internette yayınlanan dizilere yönlendirmiş haftada bir yerine birkaç bölüm birden izleme olanağı vererek izleyicinin daha da tatmin olmasını sağlamıştır (Giannantoni, 2015, s. 4).

Televizyon gün geçtikçe hedef kitlesini yitirmektedir. Özellikle genel izleyici kitlesini (25-65 yaş) kaybetmektedir. Televizyondan uzaklaşan kuşakların başında gençler ( $\mathrm{Y}$ ve $\mathrm{Z}$ kuşakları) gelmektedir. Gençler, aynı hikayelerden sıkılmıştır. Senarist Bilal Babaoğlu'na göre Türkiye'de televizyon dizilerinin tek tipleşmesinin sebebi, reklamlardır. Son gelen reklam düzenlemeleri ile kanallar yayın sürelerini uzatmışlardır. Tek bir dizi ile daha fazla reklam alma yönüne doğru ilerlemişlerdir. Televizyon izletmenin temel öğesi merak uyandırmadır. Merak uyandırması da senaryonun özgün, farklı olması ile ilişkili olmalıdır. Ayrıca televizyon dizilerinde verilen hikayeler, gerçek hayattan çok fark gözetmektedir. Televizyon dizilerindeki mahalle ortamı, ofisteki çalışma ortamı gibi gösterilen hayatlar, gerçekte öyle değildir. Televizyon bu şekilde ilerledikçe internet yapımları gün geçtikçe galip gelecektir. Günümüzde internet sayesinde herkes web dizisi çekip yayınlayabilmektedir. Bu büyük bir firsattır. Maliyet olarak web dizileri, televizyon dizilerine göre oldukça düşüktür. $\mathrm{Bu}$ yüzden bu işler belirli kişilerin elinde ilerlememektedir. Birçok kişi bu alanda var olma firsatı bulmaktadır (http://blog.milliyet.com.tr, Erişim Tarihi, 02.05.2018). Web dizilerini izleyici, onlarca seçenek arasından kendi seçerek istediği saatte izleyebilme şansını elde etmektedir. Televizyonda ise, yayınlandığ1 saat önemlidir ve her hafta beklemek gerekmektedir.

Web dizisi kavram olarak çeşitli kişiler tarafından tanımlanmıştır. Aslında pratikte televizyon dizileri ile tanımı benzerlik göstermektedir. Jennifer Hayward'a göre, seri, üst üste devam eden bölümlerin bir anlatım biçimidir. Bu yaklaşım, pratikte bölümler halinde farklı alanlarda kullanılabilmektedir. Weber ve Junklewitz de benzer tanımlar yaparak, bazı eklemeler yaparak şöyle devam etmişlerdir. Seri, bölümleri bir arada tutan, ortak fikir, tema ya da konsepttir. Bu tanımlar web dizileri için de geçerlilik gösterebilmektedir. Markus Kuhn, web dizileri kurgusal bir anlatıya sahip görsel ve işitsel biçimlerdir. Bu yüzden, web dizileri, diğer medyalardaki, öykülenmiş ve kurgulanmış erken bir iyileştirmesi olarak düşünülebilir. Bolter and Grusin 1999 senesinde, web için yeniden düzenlenmiş versiyon cümlesini kullanmıştır. Bu bağlamda, web dizileri ile televizyon dizilerine bakıldığında çeşitli benzerlikler vardır. Bunlar; bölümler, sezonlar, anlamlandırma, tekrar ve algılamadır. Aynı zamanda teknik cihazlardaki anlamlandırma formu da aynıdır. Günümüzde televizyon ve bilgisayar arasında bir fark kalmamıştır. Klein'e (2014, s. 4-5) göre web dizileri izlenirken sanal bir gerçeklik içinde hissedilmemelidir. Web dizilerinin biçimi farklıdır. Web dizileri daha 
kısadır. Bu kısalık anlatımı, temayı, öyküyü, bölümleri ve sezonları etkilemektedir. Bir diğer farklılık ise, bütçe, üretim ve dağıtımdır.

\section{Tarihsel Süreç Bağlamında Web Dizileri}

Web dizisi kavramı, ilk olarak, 16 Haziran 2006 tarihinde Bree isimli 16 yaşındaki bir genç kızın YouTube üzerinden yapmaya başladığı yayınlarla ortaya çıkmıştır. "lonliygirl15” ismiyle yapılan bu yayınlar Bree'nin ailesi ile ilgili yaşadığı zorlukları ve genel hayatı ile ilgili odasından yapılmışır. Yaklaşık yirmi bölümden sonra Bree, fanları tarafindan videoların gerçek olmadığı, her şeyin bir kurgu olduğu şeklinde eleştirilmiştir. Önceleri bu videolar çok rahatsız edici bulunmuştur. Dördüncü bölümden sonra Daniel isimli başka bir genç kendi videolarını çekmeye başlamışıı. Daniel, daha profesyonel davranarak, profesyonel ve yarı profesyonel programlar kullanarak özel efektler ve müzik gibi öğeler kullanmıştır. Fakat bu iki gencin videoları, zamanlama ve ritim açısından izleyenler açısından şüpheli bulunmuştur. Eylül 2006'da yani lonelygirl15 başladıktan birkaç ay sonra, gazeteciler, bu videoların gerçek olmadığını iddia etmiştir. Bu gelişmelerle beraber lonlygirl15 ilk web dizisi sayılmış ve web dizileri için süreç başlamıştır. Bu internet dizisi 500'den fazla bölümle üç sezon yayın yapmıştır. Lonelygirl15 medya şirketleri için bir örnek teşkil etmiş ve yeni atılımlar yapılmasına ön ayak olmuştur (Klein, 2014, s. 3-4).

1997 yllinda Reed Hastings, Amerika Birleşik Devleti genelinde müşterileri için film kiralamak için DVD-by-mail formatında bir şirket kurmuştur. Birkaç yll sonra bu şirket aktif olarak çalışmaya başlamış ve filmleri kullanıcılarına mail yoluyla kiralamaya başlamıştır. Sekiz yıl sonra bu şirket DVD-by-mail dışında işleri büyütmek ve geliştirmek amacıyla yeni bir atılım yapmışır. Posta ve nakliye masraflarını azaltmak amacıyla bu atılıma başlayan şirket, kullanıcılarının online olarak içerikleri kiralayabilmeleri için bir sistem düzenlemiştir. 2007 yilında yirmi bin seçenekle kullanıcılarına hizmet verirken kısa sürede bunu ciddi oranda arttırmış ve ilk önce Kanada olmak üzere dünyaya yayılmaya başlamıştır. Netflix ismini alan bu şirket kısa bir süre sonra DVD-by-mail sistemini tamamen durdurmuş ve tüm işlerini online olarak yapmak istemiş̧ir fakat, kullanıcılar buna tepki gösterdiği için, şirketin CEO’su Hasting, 2011 yllında iki yolu da kullanmaya başlamıştır. Bugün Netflix dünyada internet üzerinden içerik satan en büyük şirkettir (Giannantoni, 2015, s. 4-5).

Türkiye'de ilk web dizileri Youtube’ta yayınlanmaya başlamıştır. İlk olarak Şubat 2013 yllında Yolunda A.Ş web dizisi amatör olarak yayınlanmıştır. Yara Bandı, Otisabi, Ankara Kazan Biz Kepçe, 1 Kezban 1 Mahmut gibi gün geçtikçe artan web dizileri Yotube'ta amatör gençler tarafindan yapılmaya devam etmektedir. Netflix'in tüm dünyaya yayılmasından sonra Türkiye de bu alanda ilk adımları atmıstır ve ilk büyük bütçeli internet dizisi Masum, 2017 yllında Doğan Holding teşebbüsü ile BluTV tarafindan yapılmıştır. Bu web dizisi Türkiye'nin ilk profesyonel web dizisi sayılmaktadır. BluTV'den sonra piyasaya Doğuş Grubu girmiş ve Puhu TV ile en çok ses getiren yapımlardan olan Fi web dizisini çekmiştir. Profesyonel kadrolarla çekilen bu yapımlar oldukça ilgi çekmiştir.

Yukarıda belirtilen web dizileri dışında Türkiye'de BluTV, Puhu TV ve Youtube gibi platformlarda web dizileri yayınlanmaktadır. BluTV ve Puhu TV büyük yapımların kanallarıdır. Sadece web dizisi yayınlamamaktadırlar. Bol seçenekli yerli ve yabancı filmler ve televizyon dizileri de yayınlamaktadırlar. Fakat bunlara erişim ücretli olup aylık üyeliklerle olabilmektedir. Fi ücretsiz verilmiştir fakat Masum, Dudullu Postası, 7 Yüz, Şahsiyet, SıfırBir ve Dip web dizileri bu kanallarda ücretli olarak yayınlanmaktadır. Çok pahalı olmayan bu ücretlerle kullanıcı, bütün içeriklere ulaşabilme firsatı bulmaktadır. Bu kanalların önümüzdeki zamanlarda artacağı da görünmektedir. YouTube, daha çok kendi içeriğini oluşturan grupların, kendisini gerçekleştirdiği bir mecradır. Bu platformda, web dizileri de yer almaktadır.

\section{Popüler Bir Web Dizisi Olarak "Fi”}

PuhuTV'nin ilk orijinal dizisi olan Fi, Ay Yapım tarafından, Mert Baykal'ın yönetmenliğinde 20172018 yıllarında web dizisi olarak yayınlanmış bir yapımdır. Azra Kohen'in Fi-Çi kitapları senaryolaştırlmıştır. Dizi profesyonel bir kadroyla dram ve romantik türünde çekilmiştir. Fi web dizisi, televizyon dizilerinin uzunluğundan, konuların tekdüze olmasından, sansürün fazla uygulanmasından sıkılan izleyicilerin başvurduğu bir alan olan web dizilerindendir. Türkiye'de yabancı diziler yerine Türk web dizilerinin de izlenebileceğinin bir örneğidir. Dizinin her bölümü 60 dakikadan oluşmaktadır. Tamamı 12 bölümdür.

Fi web dizisinde olay örgüsü, genel olarak Can Manay isimli, zeki fakat geçmişi suçlarla dolu olan bir psikologun üstünden yürümektedir. Bu karakter televizyonda bir program sunmaktadır. Canlı yayında ünlü 
kişilere terapi yaparak özel hayatlarını herkese açarak, reyting almaktadır. Ozan Güven'in canlandırdığı bu karakter, oldukça zengin ve psikolojik sorunları olan birini anlatmaktadır. Can Manay, bebekken ailesinin onu terk etmesi üzerine büyük travmalar yașamıș ve sonra Eti adlı karakter sayesinde kendisine yeni bir sayfa açmıştır. Eti onun için bir anne, bir dost, bir sırdaştır. Kariyerinde çok iyi olan Can Manay karakteri, bir ev almak ister ve bulduğu evin komşusu olan Duru isminde birine ilk gördüğü anda aşık olmaktadır. Duru'nun iyi giden bir ilişkisi olmasına rağmen Can Manay bunu umursamaz ve Duru'ya karşı saplantılı bir aşk beslemeye başlamaktadır. Bu yüzden geçmişteki psikopat tarafı tekrar gün yüzüne çıkmaktadır. Eti onu, uyarmasına rağmen onu dinlememektedir. Duru karakterini de, Serenay Sarıkaya canlandırmaktadır. Duru, sakin bir hayatı olan, dans okuyan tutkulu bir genç kızdır. Hayatında sadece sevgilisi vardır. Fakat Duru'nun da en büyük saplantısı en iyi olmak, baş dansçı olmaktadır. Bu saplantılarla can Manay'a biraz benzemektedir. Can Manay ile tanıştı̆̆nda onun tahriklerine dayanamaz ve gerçek kişiliğini ortaya çıkarmaktadır.

\section{Teknolojik Determinizm}

Teknolojik determinizm kavramını bütün olarak tartısmadan önce "teknoloji" ve "determinizm" kavramlarına ayrı bir şekilde bakmak fayda sağlayacaktır. 1900’lere gelindiğinde teknik keşifler artış göstermiştir. Kelime olarak teknoloji, Yunanca "techner" ve " logos" sözcüklerinin bir araya gelmesiyle ortaya çıkmıştır. Techner’in anlamı yapmak, logos'un ise bilmektir. Yani teknik olan şeylerin bilgisi olarak açıklanabilmektedir. Fakat teknik ile teknoloji farklı anlamlara gelmektedir. Birbiri ile karıştırılmaması gereken kavramlardır. Teknoloji teknik gibi özel bir alanı değil toplumsal olanı ifade etmektedir. Çünkü toplumla var olmakta, toplumdan etkilenip, toplumu etkilemektedir (Atabek, 2001, s. 17-18). Heidegger, teknolojinin bir amaca bağlı olarak araç özelliğine ve insan faaliyeti olma özelliğine bakmıştır. Heidegger bu iki özelliği bir bütün olarak görmüştür. Onun tanımında teknoloji, tüm üretilip kullanılan aletlerin, makinelerin ve aygıtların kullanımı ve karşıladıkları ihtiyaçlar doğrultusunda cevap verdikleri hedeflerdir. Kullanımda olan tüm bu aletler teknolojiye bağlı olduğu kadar teknoloji de bir alet veya bir aygit olarak anlamlandırılmaktadır. Aslında teknolojiyi bir enstrüman olarak görmektedir. Heidegger, Latince olan "enstrumentum" kavramını teknoloji ile ilişkilendirmektedir. Bu yüzden teknolojinin günümüz anlamı enstrümantal (araçsal) ve antropolojik bir özellik taşıdığını vurgulamaktadır (Turan ve Esenoğlu, 2006, s. 72). Simon, teknolojiyi şöyle tanımlamıştır; insanların bilim aracıllğı ile doğaya üstünlük sağlamak için, ortaya çıkarmış olduğu bir bilimdir (Alpar vd., 2007, s. 22).

Determinizm ise basit anlamıyla, bir olayın belirlenmesi için zorunlu şartların oluşması şeklindedir. Felsefik anlamıla ise, dünyadaki hadiselerin ve özellikle beşeri olayların önceki olayların sonraki olayları belirleyecek pozisyonda birbiri ile ilişkili olması anlamına gelmektedir. Belirlemede ki kasıt, her şeyin bir nedenin olması ile beraber, ortada nedenin olması ile sonucunun da kaçınılmaz olduğu fikridir (Uludağ, 1993, s. 257). Determinizmin olduğu bir evrende her şey neden- sonuç ilişkisi içerisindedir. Yani "A" her zaman "B" "yi doğurur "B" ise "C" yi oluşturur. "B" neyin gerçekleşeceğini belirlemektedir. Yani sonuç bellidir (Taslaman, 2011, s. 4). Daha açı bir şekilde anlatmak gerekirse bu fikre göre; alınan kararlar, fikirler, olaylar, ahlaki kararlarımız önceden belirlenmiş kurallar bütünüdür. Özgür irade yoktur. Aldığımız kararlar aslında bilimsel kanunların sonucudur. İnsan iradesi nedenler sonucunda oluşmaktadır ve insan etkisi yoktur. Ortada yalnızca neden ve sonuç ilişkisi vardır. bu yüzden neden-sonuç ilişkisi determinizmin ana fikridir. (Çelik, 2007, s. 129).

Teknoloji ve onu ortaya çıkaran insan ile ilgili bağ teknoloji varlık gösterdiğinden beri hep olmuştur. Enformasyon teknolojisi de temelde teknolojik gelişmeler üstünde var olmuştur. Toplum ve teknoloji arasındaki bağlardan biri teknolojinin toplumu belirleyerek, toplumdan da aynı etkiyi görmesidir. Teknolojinin belirleyiciliği ile ilgili McLuhan ile Powers tarafindan yazılan Global Köy adlı çalışmada konu ile ilgili ayrıntılar yer almıştır. Yazılanlara göre, teknoloji, insanın duyularından herhangi birini ön plana çıkartmaya ittiğinde, diğer duyular zayıflamaya başlar ve hatta ortadan kalkmaya başlar. Bu durum insanın kendi uzantılarına ilahi bir biçimde tapınmasını beraberinde getirir. Bu açıdan daha ileri gidildiğinde ise insan kendi yaratmış olduğu makinenin yarattı̆̆1 haline dönüşür (Güven, 2008, s. 72). Teknolojik determinizm, teknolojik gelişmelerin, ekonomik gelişmeyi ve kültürel değişimi sağladığ1 fikri üstünde kurulmuştur (Atabek, 2001, s. 24). McLuhan, insan kendi düşüncesi ve organlarının bir devamı olarak icatlar yapmaktadır. Örneğin, toprağı kazmaya yarayan kürek, insan eli ve ayağının bir uzantısıdır. Mikroskop ve teleskop gibi araçlar da gözün devamıdır. Bu bağlamda her ortaya çıkan yeni teknoloji eskiyi yok etmekte veya geliştirmektedir (Altay, 2005, s. 19). 
Temelde neden-sonuç ilişkisi ile açiklanan determinizm, birçok alanla bağdaştırılan bir terimdir. Teknolojik determinizm kavramı da bu kavramlardan bir tanesidir. İletişimcilere göre, teknolojik determinizme yön veren olarak görülen Marshall McLuhan, iletişim alanında önemli çalışmalar yapmıştır. Bunlardan bir tanesi konumuz ile ilgili olan teknolojik determinizm kavramıdır. McLuhan'a göre bu kavram, insanları şekillendirmektedir. Yani kültür, ne şekilde iletişime geçildiği noktasında biçimlenmektedir. Günümüzde önemli ölçüde gelişme kaydeden iletişim teknolojisi kültürün taşıyıcısıdır. Bu yüzden iletişim teknoloji değisştikçe kültür de paralel olarak bundan etkilenerek değişmektedir. Bunun sonucunda insan hayatı değişim ve dönüşüme tabi olmaktadır. Marshall McLuhan bu kavramı en iyi şöyle açıklamaktadır. "Biz ilk bașta aletlerimize șekil veririz ve daba sonra aletlerimiz bize şekil verir". Teknolojik determinizm olgusu, bugün ve önceden neler olduğunu anlamlandırmaktadır. Ona göre bu kavram gelecek ile ilgili bir öngörüde bulunamaz. O yüzden bu kuramın teste tabi olması mümkün değildir. Bu kavramda önemli olan içerik değil araçtır (Altay, 2005, s. 21-22).

Teknolojik determinizmin fikir babası olan McLuhan'dan sonra da bu konu oldukça tartışılmışır. Bu bağlamda bu fikre olumlayıcı (iyimser) ve negatif (kötümser) olarak iki yönlü bakılmaktadır. İyimserler, teknolojiyi bir rüya gibi görmekte ve onun hayatı kolaylaştırdığını, pozitif etkilediğini savunmaktadırlar. Kötümserler ise, teknolojiyi totaliteryen bir kabus olarak görmektedir. Bu fikir teknolojinin zararlı yönleri üzerinde durmaktadırlar. Fakat her iki bakış açısında da teknolojinin belirleyiciliği üzerinde durmaktadır. Yani tarihsel olarak bir özne görevi görmektedir. Heidegger, A. Gehlen, O. Spengler, J. Ellul ve McLuhan bu anlayışı savunmaktadırlar (Çakır, 2017, s. 2). Daha açık bir ifade ile teknolojik iyimserlik, kendi iç işleyiş̧ olan ve kendi kendine bir seyir izleyen bir olgudur. Yani teknolojiyi doğal, teknolojik değişimi ise doğal bir süreç olarak kabul görmektedir. Eğer bu gelişmelere müdahale edilmezse teknoloji insanlığı mutlu yarınlara doğru götürecektir fikri hâkimdir. Bu görüşün daha ileri bir hali teknolojik hayranlık (technophilia) mertebesidir. Teknolojiye hayranlık duyan kişiler, teknolojiye çok ilgili ve teknolojiyi kullanmak için çok istekli kişiler olup, en son teknolojileri almak ve kullanmak için adeta yarış içindedirler. Teknolojik kötümserlikte ise durum negatif olarak görülmekte olup, teknolojinin belli kişiler ve grupların elinde doğay1 denetleme şeklinde işlediğinin fikri hakimdir. Bu güçlerin, teknoloji aracilığylla toplumu sömürerek, denetim altına almaya çabaladığı düşünülmektedir. Bu görüşün bir devamı ise, teknolojinin insanlı̆g tüketime, bilgisizliğe, kolaya kaçmaya ve bağımlilğ̆a itmektedir. Bu görüşün uç noktası, teknoloji korkusu (technophobia) olarak ifade edilmektedir. Bu fikirde teknoloji red görmekte, uyum sağlanmamakta, bu tür ürünlere karşı, rahatsızlık, korku ve kaygı duymak yatmaktadır. Bu aşamada olan insanlar, teknolojiden kendilerini uzak tutmaktadır (Kabakçı ve Odabaşı, 2004, s. 21). Bu iki bakış açısının ortası da teknogerçekçilik olarak adlandırılmaktadır. Teknolojik iyimserlik ve kötümserlikte de iki uç nokta olması sebebiyle bir grup teknoloji yazarı toplanarak, Mart 1998'de teknolojiye daha dengeli bakabilmek için teknogerçekçiliği ortaya atmışlardır. Bu fikir bu iki anlayış arasında bir uzlaşmayı ifade etmektedir. kendilerini teknogerçekçi olarak gören bu grubun hedefi, teknolojiye ne çok üstün tutmak ne de ondan uzak adımlar atmayı savunmak şeklindedir. Burada amaç teknolojiyi anlamak ve insan hayatında bir uyuma oturtarak hayata geçirmektir (Kabakçı ve Odabaşı, 2004, s. 21-22).

Teknolojiye iyimser ve kötümser bakış açılarının yanı sıra teknolojinin toplumla olan ilişkisini açıklamak isteyen yaklaşımlar özellikle 1970 ve 1980 yıllarında yaygınlık kazanmıştır. Bunlardan bir tanesi de teknolojinin "sosyal inşası" (Social Construction of Technology - SCOT olarak adlandirilmaktadır. Bu görüş, teknolojik determinizme karşı geliştirilmiş olan yaklaşım ile "görecelï̈in emprik programı" (The Empirical Programme of Relativism -EPOR) yaklaşımı ile güçlü ve eksik yanları eleştirilmektedir. Epor yaklaşımı, bilimsel bulguları üç aşamada toplamıştır; (www.acıkders.org, Erişim Tarihi, 18.04.2019). İlk olan bu aşama gerçek dünya ile ilgili bilimsel icatları sosyal dünyaya taşımaktadır. İkinci aşamada da bu bulunan bilimsel buluşlar sosyal sistemlerle işlenmekte ve sınırsız gibi görünmekte olan yorumsamacı esnekliğini azaltmaktadır. Son aşamada ise, sosyal sistemler bilimsel bulgu ve buluşlan kapatıp toplumsal olan ihtiyaçlara uymaktadırlar.

Sosyal inşa, teknoloji toplum ve bilim çalışmaları genelinde kapsamlı ve oldukça önemli bir kuram olmuştur. Son yıllarda, bilimsel öğeler ve teknolojik ürünlerin sosyal süreçlerin bir devamı olduğu fikri, bilim ve teknoloji sosyolojisinin alanına doğru kaymıştır. Bu bağlamda teknolojik olan sosyal yapılar olarak da görülmektedir. İnşacı yaklaşım, "sistemler kuramı", "aktör-ağ teorisi” ve "teknolojinin sosyal inşası" olarak üç şekilde hareket etmektedir. Sosyal inşa, ilk defa Berger ve Luckmann The Social Construction of Reality isimli eserinde geçmektedir. Temel fikir, gerçekliğin sosyal anlamda inşa edildiği ve bu inşa sürecinin bilim sosyolojisinin alanına girmesi gerektiğidir. Başka bir söyleyişle, toplumsal gerçeklik, insan davranış ve tutumları ile varlık gösteren kurum ve yapılardan gelmektedir. Bu bağlamda toplumsal dünyada inşa için 
gerekli olan adımlar şöyledir: İnsanların o şeyin varllğı ile ilgili davranışlarını belirleyen bilgi, o şeye karşı olan yaygın genel olan bilgi, o şey ile ilgili bilginin diğerlerine iletimi yoluyla varlığının pekiştirilmesi ve o yokmuş gibi davranılmayacak aşamaya gelinmesi.

Sosyal inşa kuramı, ilk olarak 1970’lerde Hollanda, İskandinavya, Amerika ve Birleşik Krallıkta gündem olmuştur. Burada, bilimsel olgular, doğada kendiliğinden bulunmaz, tam tersine, bilim insanları tarafindan inşa edilmektedirler. Anlatılmak istenen, doğanın bilimsel olanı dikte etmediği tam tersine bilim insanlarının bu olguları inşa ettiği şeklindedir. Sosyal inşacı kuramda anlatılmak istenen, teknolojilerin kullanım alanları içerindeki sosyal bağlamlar içinde anlam elde etmeleridir. Pinch ve Bijker'e göre, toplum teknolojilerin gelişim gösterdiği bağlam olarak anlaşılmaktadır. Daha iyi anlamak amacıyla Pinch ve Bijker'in bisiklet örneğine bakılmalıdır.

Peny Farhing bilinen ilk bisiklettir. Ön tekerlek oldukça büyük olup, arka tekerlek çok daha küçüktür. Güvenli bir bisikletin icat edilmesine kadar geliştirilen tüm modellerin tamamı düşünüldüğünde, unutulan modellerin nasıl sorunlar ortaya çıkardığı, yeni olan modellerin nasıl çözümlerle oluşturulduğu, bunların birer toplumsal kabul alması, teknolojik ürünlerin oluşumunda ve gelişiminde etki sahibidir (Kara, 2017, s. 120-125).

Jenkins'e göre; yeni medya, tarihsel olarak kendinden evvelki medya sistemlerini ve içeriklerini etkilemektedir. Fakat bu anlatım eski olan her şeyin yok olduğu anlamına gelmemektedir. Bu bağlamda eski ile yeni yakınlaşmaktadır. Eski olan tam olarak yok olmamakla beraber yeni olana eklenmektedir. Bu akış bazen işbirliği ile bazen de zıt bir yönde devam etmektedir. Tüketiciler, akışın içerisinden istedikleri içerikleri yeni medyada bulmakta ve o içeriği tüketmektedir. Bununla beraber tüketiciler zaman zaman içerik de üreterek üretici konumuna geçebilmektedirler. Yani ortaklaşa bir iş çıkmaktadır. Jenkins, yöndeşmenin öneminden de bahsederek web 2.0 ile kullanıcıların pasif konumdan aktif konuma geçebildiğini ve birçok aktiviteyi bir mecradan gerçekleştirdiğini vurgulamaktadır. Bu bağlamda insanlar bilmediklerini bu mecralardan almakta bildiklerini ise bu mecralarla paylaşmaktadır. Yani kolektif bir zeka iş başındadır. Jenkins, yeni medyanın bireylere kolektif zekayı getirdiğini düşünmektedir. Ayrıca, bu paylaşım ağı içerisinde medya içeriklerinin artmasıyla medya sahipliğinin de çeşitlendiğini savunmaktadır. Medya sahipliğinde oluşan tekelleşme, fikir olarak fakirleşmeye sebep olacak ve paylaşım kültürünü olumsuz etkileyecektir. Bununla beraber üretilen içeriklerin halka ulaşmasında kısıtlamalar olacak ve eşik bekçileri ortaya çıkacaktır. İnsanlar bu eşik bekçilerinin izin verdiği sürece içeriğe ulaşabileceklerdir. Fakat Jenkins, medyanın her köşede olduğunu ve bireylerin buna rahatlıkla ulaşabildiğini söylemektedir (Bereket, 2018, s. 21).

Fuchs, Jenkins’in yeni medya ile ilgili yaptı̆̆ birçok söyleme katılmamaktadır. Fuchs, internetin hem üretici hem de tüketici olarak kullanılmasına şöyle bakar; interneti kullananlar internet ürün pazarının büyüdügünü gözlemlerler ve aynı zamanda kullanıcının üretmiş olduğu içeriği, yaratıcı, kalıcı, iletişim, etkinlik, topluluk inşası ve içerik üretiminde olduklarını fark etmeye başlarlar (Uzunoğlu, 2015, s. 187). Fuchs, insanlara özgürlük, yaratma-üretme imkanı veren bu ağın sahibi kimlerdir veya hangi şirketlerdir ve bu ağın gücünden kimler fayda sağlamaktadır? Sorularını sormaktadır. Bu bağlamda Fuchs, Jenkins'i eleştirmekte ve bu ağın kazancını görmezden gelmesiyle eleştirmektedir. Aynı zamanda insanların ağdan diledikleri bilgiye ulaşmaları ve yararlanmalarını zaten çok ağır bir bedel ödeyerek yani modern köleler olarak emekleri sayesinde sahip olduklarını söylemektedir. Fuchs, yeni medya ile değişen kitle iletişim araçlarının kurallarını kimlerin koyduğunu sorgulamaktadır. Kullanıcıların, aldığı her bilginin ve paylaştı̆̆ her bilginin bireyi "internet üreten tüketici" metasına dönüştügünü belirtmektedir. Örnek olarak, hizmetleri ücretsiz sunan Google kullanıciları, aslında "internet üreten tüketici" metasına dönüşmektedirler. Kuralları koyan Google kullanıcıların bilgilerini ele geçirmekte ve buna göre kullanıcıları bir tüketim malzemesi olarak görerek reklam verenlere tüketicileri satmaktadır. Fuchs bu sistemin bir kandırmacaya dönüştüğünü belirtmektedir. Akıllı telefon üretimi için Afrika'daki işçiler madenleri çok zor şartlar altında çıkarmaktadır ve aynı zamanda da Çin'de de işçiler bu telefon üretimini çok düşük maliyetlerle çalışarak emeğini satmak zorunda bırakılmaktadır. Bunun sonucunda bu akıllı telefonlar çok ciddi fiyatlara satılmaktadır (Bereket, 2018, s. 21-22). Yeni medyadaki gözetim sorunu üzerinde de duran Fuchs, dataların sürekli sermaye sahiplerine satılarak insanların tüketim için kullanıldıklarını belirtmektedir (Illhan ve Aydoğdu, 2015, s. 58). 
Teknolojinin bu denli yaygın kullanılması ve sonucunda insana etkisinin bu kadar büyük olması çeşitli kavramların ortaya çıkmasını sağlamıştır. Bu bağlamda 19. yüzyılda özellikle tren gibi araçların kullanılması iletişim alanında teknolojik belirlenimcilik fikrinin ortaya çıkmasını sağlamıştır. Bu bağlamda raylar gelişmenin bir göstergesi sayılmıştır. 1950 ve 1960’lı yıllara gelindiğinde ise belirleyicilik kavramı modernleşme olarak eklemlenmiştir. İletişim araçlarının yaygınlaşması 1970 ve 1980'lerde tüm dünyayı küresel bir köye dönüştürmüştür. 1990 ve 2000’lerde ise küresel kent kavramı ortaya ç1kmıştır. Bu bağlamda teknolojik determinizm kavramını savunanlara göre; 1990 ve 2000’li yıllarda bilgisayar ve internet teknolojisi gibi kavramların gelişmesi ile dünya küreselleşmiş ve bilgi toplumu kavramı ortaya çıkmıştır. Gidilen her yerde bilgisayar ve internetin olması insanın her yerde bilgiye erişebilmesini sağlamıştır. Fakat bu durum amacına uygun mu kullanılmaktadır ya da insanı gelişime mi götürmektedir tartışılmalıdır (Erdoğan ve Alemdar, 2010, s. 142).

\section{Fi Dizisine Yönelik Nitel Bir Araştırma}

Çalışmanın bu kısmında, Fi internet dizisine yönelik araştırma yapılacak olup, araştırmanın modeli, evren ve örneklemi, veri toplama araçları, bulgular ve yorumları hakkında bilgiler mevcuttur.

\section{Araştırma Yöntemi}

Bu çalışmada, teknolojik determinizm kuramıyla Türkiye'de çok yeni bir alan olan web dizilerinin toplumsal dönüşüme etkileri araştırılmış ve Fi internet dizisi örnek olarak çalışılmıştır. Araştırmanın yöntemini, içerik analizi oluşturmaktadır. Nitel bir araştırma yöntemi olan içerik analizi yöntemi, nitel araştırma yöntemleri içerisinde en sık başvurulan yöntemlerden birisidir. Bu yöntem, daha çok görsel ve yazılı bilgilerin analiz edilmesine dayanmaktadır (Özsarı vd., 2016, s. 211-212). İçerik analizi yöntemindeki ana amaç, bir araya getirilen verileri açıklayabilecek olgulara ve kavramlara ulaşmaktır. Betimsel analizde, işlenen konular ve veriler, içerik analizi yönteminde daha derinlikli bir şekilde incelenmektedir. Bu yüzden toplanan verilerin ilk olarak kavramsallaştırılması sonra da ortaya çıkan kavramların düzgün bir biçimde düzenlenmesi ve verilerin saptanıp açıklanması gerekmektedir (Yıldırım ve Şimşek, 2005, s. 227).

\section{Evren ve Örneklem}

İnternet tüm dünyada aktif olarak televizyonu da içine alarak yaygın kullanılan bir kitle iletişim aracına dönüşmüştür. Televizyonda en çok tercih edilen türlerden biri olan diziler internette de bugün en çok izlenen türlerden birisidir. İnternet dizileri çalışmanın evrenini oluşturmaktadır.

$\mathrm{Bu}$ çalışmanın örneklemini Fi internet dizisinin ilk sezonunun son 5 bölümü (8. 9. 10. 11. 12.) oluşturmaktadır. Dizi iki sezondan oluşmaktadır. Tüm bölümler izlenmiştir. İlk sezonun seçilmesinin sebebi ilk ses getiren sezon olmasıdır. Dizinin son 5 bölümünün (8. 9. 10. 11. 12.) seçilmesinin sebebi ise, olay örgüsünün daha hareketlenmesi, sponsor ve reklam veren şirketlerin ilk bölümlere oranla daha fazla görünür olması, teknolojik öğelerin daha baskın olması ve dizinin kuramla daha örnek verilebilir sahnelerinin olmasıdır. Dizinin son 5 bölümü (8. 9. 10. 11. 12.) izlenmiş ve başta teknolojik determinizm olmak üzere çeşitli kuramlarla olan bağlantısı içerik analizi yöntemi ile incelenmiştir.

\section{Veri Toplama Araçları}

Çalışmada, web dizileri evreni ve Fi web dizisi örneklemi teknolojik determinizm kuramı çerçevesinde içerik analizi yöntemi ile incelenerek literatürde var olan veri toplama araçları taranmış fakat çalışma nicel bir araştırma olmadığı için net bir şekilde eşleşen bir veri toplama aracı bulanamamıştır. Bu durum sosyal bilimlerde karşılaşılan sorunlardan bir tanesidir. Bu yüzden çalışmaya en yakın görülen veri toplama araçlarından gözlem metoduyla araştırma yapılmıştır.

Sosyal bilimler de diğer tüm bilimler gibi deneysel bir özellik taşımaktadır. Dolayısıyla olgulardan yola çıkmaktadırlar. Sosyal bilimlerde ana öğe olguları sistemli bir şekilde ortaya çıarmak ve onları gözlemlemektir. Gözlemsel araştırmada izlenen iki tür yöntem vardır. Bunlar (Duverger, 1973, s. 94-95);

- Yazılı olan belgeler; fotoğraflar, filmler, gramofon plakları gibi sosyal olaylara 1şık tutan belgelerin analizi

- Soruşturma, mülakat ve soru kağıtları aracıllğıyla sosyal olguların ve gerçeklerin dolaysız olarak gözlemlenmesi

Burada araştırmanın alanını yazılı belgelerin içine giren fotoğraflar, filmler ve gramofon plakları gibi olaylar içermektedir. Bahsi geçen kategoriye diziler de alınabilir. Filmler, fotoğraflar, törenler, festivaller, 
siyasal gösteriler, ayaklanmalar sosyal olayların kayıt altına alınabilmesini sağlamıştır. Bu sayede sosyal bilimciler bu belgeleri inceleyerek bazı gerçekleri açığa çıkarmışlardır. Bazı olguları açıklamak için bazen kitaplar, arşivler yazılı belgeler yetmemektedir. Örneğin, Nuremburg kongresinin film ve fotoğraflarından, Nazilerin gösteri yürüyüşlerinden, Hitlerin söylevlerinin filmlerinden gibi çok çeşitli yazılı olmayan belgeler elde edilmiştir (Duverger, 1973, s. 94-95).

\section{Bulgular ve Yorum}

Çalışmanın örneklemini oluşturan Fi web dizisinde teknolojik öğelerin fazla oluşu teknolojik determinizm kuramını akillara getirmektedir. Dizinin birinci sezonunun son 5 bölümleri olan 8, 9, 10, 11, 12. analiz edildiği diziye bakılacaktır.

Televizyondaki tüm programlara sansür uygulayabilen RTÜK bir bakımdan televizyonun izleyici kaybetmesine sebep olmuştur. Sahnelerin sansürlenmesini istemeyen izleyici kendisine alternatif yollar aramış nitekim de bulmuştur. İnternet sansürden kaçan izleyiciye bir çözüm olmuştur. RTÜK, sigara, alkol, küfür, şiddet, kan ve müstehcen sahnelere televizyonda sansür uygulamaktadır. İzlenen içeriğin bütünlügünün bozulduğunu düşünen izleyici, sahnelere bu şekilde müdahale edilmesinden rahatsızlıklarını çeşitli platformlardan her seferinde dile getirmektedir.

Televizyon dizilerinin izleyiciyi en çok rahatsız eden yönleri, sürelerin çok uzun olması, gereksiz uzatılan sahneler ve konuların tekdüze olmasıdır. Türk televizyon dizilerinin çok uzun olma sebeplerinden biri de reklamlardır. Reklamlar tek diziye yöneldikleri için süreler uzamıştır. Televizyon reklamlarına maruz kalmak istemeyen izleyici reklamın olmadığı web dizilerine yönelip aradığı içeriği bulabilmektedir. Ayrıca teknolojik gelişmelerle beraber internet bir telefon kadar uzakta olduğu için, televizyona ulaşmaktan daha kolaydır. Televizyon dizilerinde kanal değiştirmeye rağmen ilerleyemezken internette istediğini kolaylıkla izlemek kullanıcıları web dizilerine yöneltmiştir. Web dizilerinin sürelerinin kısalı̆̆ı, konuların daha farklı ve daha yaratıcı olması, oyunculuğun ve kadronun sansüre ve kurallara çok bağımlı kalmadan daha özgür oluşu ve daha profesyonel olması televizyon dizilerine göre tercih edilmesine sebep olmaktadır. Fi web dizisinin izlenmesinin ve tutmasının en büyük sebepleri arasında konunun farklı, süresinin kısalığı ve sansürün olmayışı sebebiyle oyunculuğun daha özgür bırakılmasıdır.

Reklam, herhangi bir ürünün, hizmetin veya fikrin ruhuna, yaratılısıına ve hedefine uygun bir biçimde tanıtılması, mesajın doğru kanallar yoluyla doğru bir şekilde hedef kitlesine iletimi olarak tanımlanmaktadır. (İsler, 2014, s. 111). Reklam yapımcıları son yıllarda, hedef kitleleri bağlamında reklamın daha etkili olması için, değişik arayışlara girmişlerdir. Bunlardan bir tanesi de ürün yerleştirmedir. Ürün yerleştirme, işitsel görsel, kitle iletişim araçları yoluyla potansiyel olabilecek projelerde, reklamı yapılmak istenen ürünün öyküye iyi bir şekilde yerleşimi sonucu oluşturulan bir pazarlama şeklidir. (Doğan ve Özdemir, 2017, s. 1162). Başka bir deyişle belli bir ücret karşılığında ajans, kurum veya iletişim kanalı arasında belli bir anlaşma ile devam ettirilen mal veya hizmetlerin reklamlarının açık bir biçimde yapıldığı reklamlara ürün yerleştirme reklamlanı denir (Oğuzcan ve Hajıyev, (2018, s. 205-206). Ekranda sunulan ürün olmasına rağmen aslında verilmek istenen markadır. Fakat RTÜK 6112 sayılı kanununda ürün yerleştirme olarak kullanımda bulunmuştur (Akgül, 2013, s. 593-594).

Dünyada oldukça popüler olan Netflix Türkiye'de de büyük bir kitleye sahiptir. Gelirlerini ise üyelikten sağlamaktadır. Türkiye'de BluTv de Netflix gibi gelirlerini üyelikten sağlamayı tercih etmiştir. Fakat Puhutv, Netflix ve BluTv gibi gelirini üyelikten sağlamamaktadır. İçeriklerini üyelik ve ücret almadan erişime açmaktadır. Bunun bir sebebi Türkiye'de insanların para ödemek istememeleri gibi görünmektedir. Bunu öngören Puhutv farklı olduğunu düşündüğü ama aslında televizyondan sürekli alş̧1k olunan bir sistemi kullanmak istemiştir. Bu sistem reklamların dizi içeriklerine ürün yerleştirme şeklinde verilmesi ve ayrıca televizyon reklamlarındaki kadar uzun olmayan üç veya dört reklamlık reklam aralarının verilmesidir. Puhutv, Fi web dizisinde yiyecekten, giyecek ürünlerine, elektronikten beyaz eşya ürünlerine, araba reklamlarına kadar birçok ürünün reklamını yapmaktadır. Giderlerini karşılamak için mutlaka bazı yollardan gelir elde etmek gerekmektedir. Bu yol reklam da olabilmektedir. Fakat Puhutv ya da Fi web dizisi bunun ölçüsünü kaçırmış ve reklam verme olayını abartmıştır. Tükenene kadar tüket (Aydoğan, 2005, s. 44) algisiyla izleyicilere mesajlar gönderilmektedir.

Başta dizinin sponsoru olan Vodafone dizinin başlangıcından sonuna kadar içerikten, ürün yerleştirmeye kadar sıklıkla görülmektedir. Karakterler neredeyse her telefon kullandığında üstte Vodafone yazısı görünmektedir. 

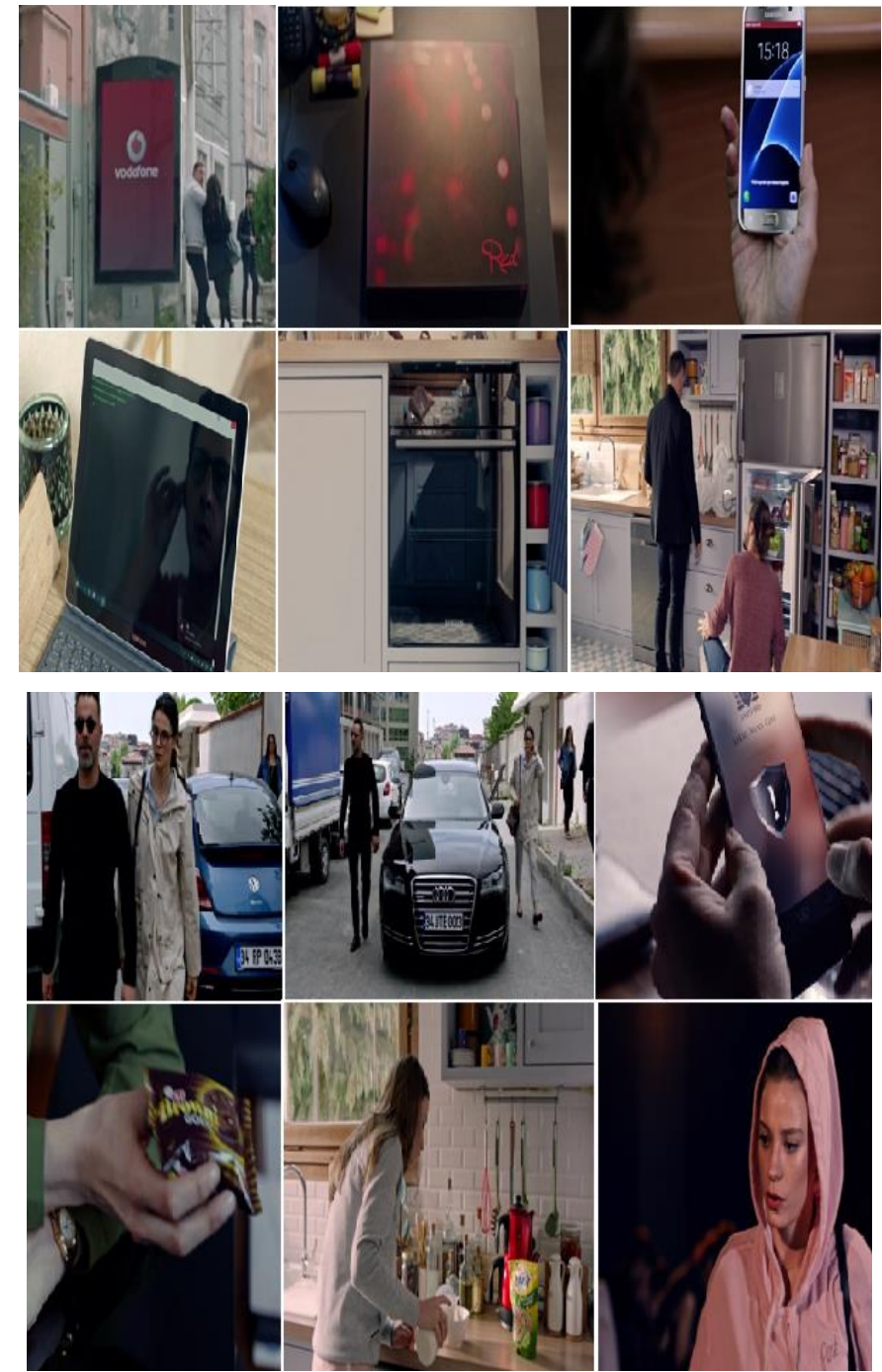

Görsel 1. Fi Web Dįìis 8. 9. 10. 11. Bölümlerdeki Ürün Yerlestirme Yöntemiyle Gösterilen Reklamlar

Bir diğer reklamı yapilan firma olan Samsung ise dizide Vodafone’u da geçen reklam yoğunluğu oldukça fazla olan bir firma olarak göze çarpmaktadır. Tüm karakterlerinin kullandığ1 telefon, tablet, bilgisayarlar Samsung'tur. Bu ürünlerin reklamları da ürün yerleștirme yöntemi ile verilmektedir. Neredeyse her telefon kullanıldığında telefonun üzerindeki Samsung yazısı net olarak gösterilmektedir. Bunun dışında da telefonların özelliklerine de hikayede zaman ayrılmakta ve reklama hiçbir zaman ara verilmemektedir. Çamaşır makinası, bulaşık makinası, buzdolabı gibi evdeki birçok teknolojik cihaz Samsung'tur. Dizinin hikayesine ustalıkla yerleştirilen bu reklam sahneleri izleyenlere reklam olduğu bile hissettirilmemektedir. Sanki hayatın bir akışı gibi gösterilmektedir. Dizide sürekli olarak bu ürünleri kullanın ve siz de bu hayata sahip olun mesajı verilmektedir. Geçmişte insanların gereksinimlerinden tutumluluk sebebiyle vazgeçmeleri erdem olarak görülmekteyken günümüzde bu durum tam tersine dönmüştür. Tüketim artık bir erdem haline dönüşmüştür (Aydoğan, 2005, s. 44). Dizide özellikle teknolojik cihazların markalarının görünümünden ziyade ürünlerin nasıl kullanılacağı ve özellikleri ile ilgili de çok fazla sahne yer almaktadır. Samsung buzdolabının reklamı yapılırken çok fazla gida sığacağı ve dondurucu bölümünün de soğutucuya çevirtilip daha fazla yiyecek yerleştirilebileceği özelliği izleyiciyle paylaşılmaktadır.

Bir diğer reklamları yoğun olarak yapılan ürün araba reklamlarıdır. Farklı markalara sahip çeşitli arabalar sıklıkla gösterilmektedir. Dizide tanıtımı verilen birçok reklam üst gelir seviyesine sahip olabilecek kişilerin alabileceği ürünlerdir. Bu durum izleyicilerin grafikler üzerinde gelir durumlarına ayrılığını ve alım gücüne göre reklamlar verildiğini göstermektedir. Bu bağlamda dizinin gelir seviyesi düşük kişileri hedeflemediğini göstermektedir. Bunu şuradan da anlayabiliriz birçok ünlü kişi magazin programlarında bu diziyi izlediğini belirtmiştir. Bu durum neden Masum web dizisi ya da Sıfır Bir web dizisi için 
yapılmamaktadır. Gelir seviyesi oldukça yüksek olan çevrelerce izlenen bu dizi hedef kitlesine ulaşmıştır. Günümüzde, tüketim olgusu, üst sınıfların elinden çıkmış, orta sınıfın dahi kendini kontrol edemediği bir olgu haline dönüşmüştür. Medyanın yayınladığı reklamlar izleyiciye mutluluğun tüketmekte olduğunu iletmektedir (Aydoğan, 2005, s. 44).

McLuhan'ın deyimimle reklam, 20. yüzyılın mağara sanatıdır (Elden ve Bakır, 2010, s. 9). Bu yönüyle kültürü her dönem taşımaktadır. Bu çağda, reklam yalnızca ürünlerin satışını artırmak için değil kendisini ve ürünlerini anlatabilmek amacıyla neyi, nasıl, neden, nereden, kim için, hedef kitlelerine ilettiği bir çeşit iletişim biçimidir (Elden ve Bakır, 2010, s. 10). Bu bağlamda bu dizide de üreticiler tüketicilerine ulaşabilmek için reklamı kullanmışlardır.

Tablo 1. Fi Dizisi 8. 9. 10. 11. 12. Bölümleri Reklam Analizi

\begin{tabular}{cccc}
\hline & Fi Dizisi 8. 9. 10. 11. 12. Bölümleri Reklam Kullanımlart & Toplam \\
\hline \multirow{2}{*}{ Bölüm } & $\begin{array}{c}\text { Teknolojik Ürün } \\
\text { Reklamlart }\end{array}$ & Diğger Reklamlar & 10 \\
8. Bölüm & 9 & 1 & 11 \\
9. Bölüm & 11 & - & 14 \\
10. Bölüm & 13 & 1 & 10 \\
11. Bölüm & 6 & 1 & 9 \\
12. Bölüm & 8 & 1 & \\
\hline
\end{tabular}

Tablo 1'de Fi dizinin 8. 9. 10. 11. 12. bölümlerinin markaları gösterilerek teknolojik olan ve olmayan ürün reklam sayıları toplam olarak gösterilmiştir. Sonuç olarak bakıldığında ise insan ihtiyaçlarının kitle iletişim araçları yoluyla, reklam yoluyla yönlendirildiği görülmektedir (Aydoğan, 2005, s. 8).

\section{Teknolojik Determinizm Bağlamında Fi Web Dizisi}

Teknolojik determinizmin temelinde yatan neden sonuç ilişkisi değişimi de beraberinde getirmektedir. Değişim teknolojiye de tanık olmuş ve durmaksızın devam etmektedir. Yunan filozof, Heraklitos'un değişim ile ilgili “aym ırmaklara girenlerin üzerinden farkh sular akar” sözü konu ile ilgili açıklayıcıdır. Aslında burada anlatılmak istenen, ruhsal ve düşünsel olan değişimdir. Değişimin sürekliliği için kullanılan ırmak metaforu önemli bir noktaya değinmektedir. Giddens, bu noktada değişim ve dönüşümün birbirine karıştırılmaması gerektiği vurgusunu yapmaktadır. Ona göre dönüşüm eskisine benzemeden yaşanmaktadır. Değişimde ise, eski bazı değerlerin sabit kalması fikri vardır. Değişim bazen bir etkene bağlı olsa da çoğunlukla çeşitli etmenlerden ortaya çıkmaktadır. Bu bağlamda toplum gibi büyük bir olgunun değişiminde tek bir etkenden söz edilemez. Teknolojik gelişmeler de bu bağlamda toplumsal değişimin belirleyicisidir (http://sahipkiran.org, Erişim Tarihi, 17.04.2019).

Teknolojik determinizmin ana kaynağında aydınlanma dönemi ve 19.yy sosyal bilimcileri başta olmak üzere rol alarak özerk teknoloji mitini irdelemişlerdir. Bu mite göre teknoloji, kurumsallaşma şekillerinden sosyalleşme evresine kadar toplumsal olanın her alanını belirlemektedir. Bu açıdan teknoloji, bireylerin eylemlerini güçlü bir biçimde kuşatan veya onları belirleyen dışsal bir güçtür. Teknoloji, bireysel ortamlardan kurumsal ortamlara, kişisel iletişimden kitlesel iletişime bütün toplumsal alanları biçimlendirmektedir (Altun, 2003, s. 8). Marshall McLuhan'ın ileri sürmüş olduğu teknolojik determinizm savında her türlü değişimin sebebi teknoloji olarak görülmektedir. Bu noktada McLuhan teknolojiyi hayatın merkezine koymuş ve insan bedeninin bir devamı olarak görmüştür (Altay, 2005, s. 15).

Çalışmanın evrenini oluşturan web dizileri başta dünyada olmak üzere Türkiye'de de çok takip edilen türlerdendir. Yeni olan bu alan hızla gelişmektedir. Türkiye'de profesyonel olarak web dizilerini yayınlayan PuhuTV ve BluTV gibi web kanalları hızla gelişim göstermekte ve televizyon izleyicisini bu platformlara çekmektedir. 12 bölümlük Fi web dizisi ve Çi’nin ilk 3 bölümü toplam olarak 100 milyon izlenme sayısına ulaşmışır. Bu 15 bölüm 17 milyon kişi tarafından izlenmiştir. Ortalama olarak dizinin her bir bölümü 6.66 kişi tarafindan izlenmiştir. Bu da 13.5 reytingine denk gelmektedir (http://m.haber7.com/, Erişim Tarihi, 18.04.2019).

Günümüzde bizi çevreleyen ortam ya da süreç, elektronik teknolojisi, toplumsal yaşamdaki ilişkileri ve kişisel yaşamı çepeçevre sarıp biçimlendirmektedir. Bazı kesimlerce sorgulanan, bazı kesimlerce ise sorgulanmayan bu süreç, neredeyse tüm düşüncelerimizi, eylemlerimizi, kurumlarımızı, en başından gözden geçirip, yeniden düşünmemizi gerektirmektedir. Çünkü her geçen gün her şey değişmektedir. Bireyler, aileler, komşular, eğitim, iş, devlet bütün toplumsal ve kişisel ilişkiler dramatik bir şekilde değişime maruz kalmaktadır. (McLuhan ve Fiore, 2005, s. 8). Bu bağlamda bu değişimler Mcluhan'in (2005, s. 12) deyimiyle bireyi şöyle etkilemiştir; 


\begin{abstract}
"Kaç para kazanyorsunuz? Intihar düsündünüz mü hiç? Bunu simdi mi düsündünüz daha önceleri de düsünmüss müydünüz? Ne yaptığınızın farkında mısını?? Isste buradayım, kendimle yüz yüreyim... Evrensel, tiranca bir gözetim, hem de ana rabminden mezara kadar gözetim altındayı. Bu durum, özel hayatımız olmal dememizle, toplumun her seyi bilme gereksinimi arasinda berbat bir ișlem yaratiyor. Eskinin geleneksel, özel, kisisel düsünceleri, eylemleri - mekanik teknolojinin kaliplar - elektronik enformasyon kaynt kuyutlarnca, bir anda her şeyi bilgisayara yükleyen yeni enformasyon kaynt kuyutlama yöntemlerince tehdit altında. Bunlar, sanki affetmeyi bilmeyen, hiç unutmayan, bağsslamayan, eski günlerdeki "yanlıslarımız?" kaynttan düsmeyen devasa bir dedikodu sayfas gibi. Medyanm verdiği bilgiyle ve medyanın hepimizin üzerindeki total etkisiyle basa çkabilmek için bir çare bulmanın zaman geldi de geciyor bile. Herkesin berkesin yapıp ettiğiyle bu kadar uğraștığı, hepimizฺin bir toplumsal değişimin amelesine dönüstüğ̈̈ günümüz dünyasina nasıl gelip dayandık? Bunu kim proglamladt? Bu ne istir?..."
\end{abstract}

McLuhan'ın birey ile ilgili söylediği bu sözler, teknoloji ile beraber ortaya çıan, bireyin kameralar veya bilgisayar kayıtları aracılığılla her an ve her yerde gözetlenmesini anlatmaktadır. Gerçekte maruz kalınan bu durumu ayrıca kitle iletişim araçları da pekiştirmektedir. Bu durum filmlere, dizilere, ayrıca da konu olmaktadır. Fi web dizisi de bu durumu pekiştiren, sanki normal bir olaymış gibi gösteren ve izleyiciye duyuran dizilerden biridir. Dizinin ilk sezonunda ve son $5(8,9,10,11,12)$ bölümünde daha yoğun görülen Can Manay karakterinin Duru Durulay karakterini gizli kameralarla izlemesi örnek olarak gösterilebilir. Olayda özel hayata saldırıda bulunan Can Manay karakteri, teknolojik gelişmelerin ortaya çıkardığı kameralar ve bilgisayarlar yoluyla kişisel hayata saldırıda bulunmaktadır. Bu tür olayların dizi ve film içeriklerinde işlenmesi olayların normalleşmesine sebep olmaktadır. Nitekim benzer olaylar gerçek hayatta yaşanmaktadır. Örnekleri de zaman zaman medyaya yansımaktadır. Bu durumdan şu sonuç çıkmaktadır. Kameralar, günümüzde iyiye kullanıldığı kadar kötüye de kullanılmaktadır. Bu durum akıllara teknolojik determinizm kavramını getirmektedir. Bu bağlamda teknoloji iyiye mi kullanılmaktadır ya da kötüye mi kullanılmaktadır. Ayrıca bazı sahnelerde bilgisayarlar aracılığı ile güvenlik sistemlerinin şifreleri de kırılmaktadır. Dizide geçen bu örneklerde kötüye kullanılmaktadır. Dizideki birçok teknolojik cihaz, eşya sıklıkla gösterilmektedir. Beyaz eşyalar ve elektronik aletler hayatı kolaylaştırmak için kullanılan öğeler olarak karşımıza çıkmaktadır. Bu açıdan da teknoloji hayatı kolaylaştırmaktadır.

Dizi adeta teknolojik cihazlarla çepeçevre sarılmıştır. Her sahnede göze bir cihaz çarpmaktadır. Aslında içinde bulunduğumuz durum da tam böyledir. Teknolojik cihazlar her bir yanımızı sarmıştır. Dizi Özünde reklam ağırlıklı olduğu için izleyicilerine neyi satın alması gerektiğini ögütlemektedir. İzleyici de sanki kendi özgür iradesi ile satın almış gibi dizideki o teknolojik cihazları almaya yönelmektedir. Teknolojinin yaratıcısı olan insan zamanla onun etkilerine olumlu ya da olumsuz şekilde maruz kalmaktadır. Bu bağlamda bu cihazlar zaman zaman insan denetiminin dışına çıkmaktadır. Ve bir yörüngeye girerek insan hayatının devamını değiştirmektedir. Tıpkı Duru karakterinin bir anda kameralarla, cihazlarla izlenerek hayatına yön verilmesi gibi hayatın seyri değişmektedir. Bu yüzdendir ki teknolojik determinizmin gücünün farkında olan politika mercileri veya kurumlar, bu etkiyle gücü kullanarak kitlelere yön vermektedirler. Can Manay karakteri de buna benzemektedir. Teknolojik gücü kendi çıkarları için sonuna kadar kullanmaktadir.

Teknolojik cihazlara tarih boyunca insanlık yön vermiştir. Günümüzde ise durum büyük eleştiri odağ1 olmuştur. Teknolojik determinizm de bu noktada ortaya çıkmıştır. McLuhan'ın (2005, s. 22) şu söylemi

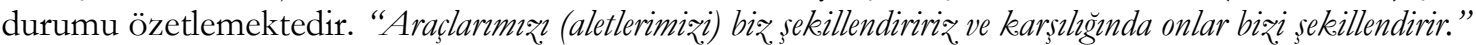

Tablo 2. Fi Diæisisi 8. 9. 10. 11. 12. Bölümleri Teknolojik Determinizm Kullanm Analizi

\begin{tabular}{|c|c|}
\hline Bölüm & Teknolojik Determinizmin Rolü \\
\hline 8. Bölüm & Furkan karakterinin internet üzerinden GPS ile medya patronu olan Sadık Murat Kolhan karakterini bulması \\
\hline 9. Bölüm & $\begin{array}{l}\text { Can Manay karakterinin önceden ayarlamış olduğu hemşire yoluyla saplantılı aşık olduğu kadınla telefonla } \\
\text { fotoğraflarını gizliden çektirmesi ve bu fotoğrafı kötüye kullanmak istemesi }\end{array}$ \\
\hline 10. Bölüm & $\begin{array}{l}\text { Furkan karakterinin, Can Manay karakterinin ofisine kapıdaki alarmı interneti kullanarak etkisiz hale getirip } \\
\text { girmesi ve olayın sonucunda balkondan aşağıya düşerek ölmesi }\end{array}$ \\
\hline 11. Bölüm & Can Manay karakterinin Duru karakterini gizli kameralarla sürekli izlemesi ve hamlelerini ona göre yapması \\
\hline 12. Bölüm & $\begin{array}{l}\text { Furkan karakterinin ölmeden önce özge karakterine bıraktığı sesli mesaj yoluyla gerçeğin ortaya çıkmasını } \\
\text { sağlaması }\end{array}$ \\
\hline
\end{tabular}

Yukarıdaki tabloda görüldüğü gibi teknoloji her yeri sarmıș ve özel alan bırakmamıștır. McLuhan'ın

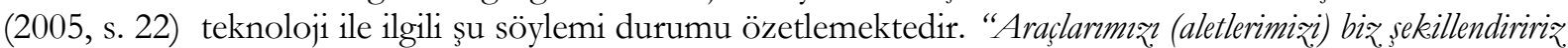

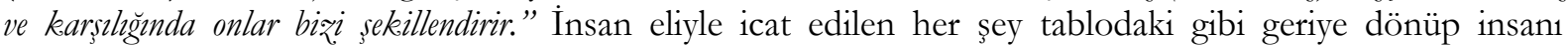


etkilemektedir. 8. bölümde görülen "Furkan karakterinin internet üzerinden GPS ile medya patronu olan Sadık Murat Kolhan karakterini bulmasi" ifadesi insan eliyle icat edilmiş bir sistemin tekrar insanı olumlu ya da olumsuz yönden etkilediğini göstermektedir. 9. bölümde "Can Manay karakterinin önceden ayarlamıș oldư̆u bemşire yoluyla saplantıl aşı olduğu kadınla telefonla fotoğraflarm givliden çektirmesi ve bu fotoğrafı kötüye kullanmak. istemesi" örneği, teknolojinin onun gücünün farkında olanlar tarafindan yönlendirilebileceğini göstermektedir. 10. bölümdeki örnekte, "Furkan karakterinin, Can Manay karakterinin ofisine kapıdaki alarmı interneti kullanarak etkisiz hale getirip girmesi ve olayn sonucunda balkondan aşağgya düsserek ölmesi" teknolojik cihazlarla olayların seyrinin değiş̧iği görülmektedir. Bu örnekte olaylar planlandığı gitmemekte ve Furkan karakteri olay sonucu ölmektedir. 11. bölümde, "Can Manay karakterinin Duru karakterini giə̨li kameralarla sürekli i₹lemesi ve hamlelerini ona göre yapması" örneğinde bu karakterin teknolojik cihazlarla izlenmesi sonucu özgür iradesi ile karar vermesi engellenmekte ve teknolojinin belirleyiciliği ön plana itilerek olayların seyri değişmekte ve değiştirilmektedir. Çalışmanın son bölümünü oluşturan 12. bölümde ise, "Furkan karakterinin ölmeden önce özge karakterine buraktı̆̆ı sesli mesaj yoluyla gerreğgin ortaya çıkmasin sağlaması" örneği ile de yine teknoloji bıraktığı izlerle gelişen olayların seyrini değiştirmektedir. Verilen örneklere bakıldığında teknolojinin bu dizide olduğu gibi insan hayatının merkezinde olduğu ve yaşamları nasıl değiştirdiği gözlemlenmektedir. Sonuç olarak teknolojinin kullanılışı ağırlıklı olarak olumsuz yönde olduğu için teknolojik kötümserlik çalışmanın kuramını belirlemektedir.

\section{Sonuç ve Tartışma}

Tüm bu anlatılanların ışığında günümüzde çok büyük bir teknolojik patlama, teknolojik gelişme çağı yaşanmaktadır. Bir bilgisayar, çok uzun zamanlarda bitirilemeyecek her türlü işlemi çok kısa zamanlara sığdırabilmekte ve geçmişte insanın yaptı̆̆ her işi yapabilir konuma gelmiştir. Bilim ve teknoloji ışığında, tüm dünyada insanların hayat standartları değişmiştir. Fakat bu teknolojik gelişmeler beraberinde bazı sorunları da getirmektedir. Teknolojik gelişmeler son zamanlarda doğanın dengesinin bozulmasına sebep olmuş ve insanların bu denli hızlı gelişmelere adapte olamamasından dolayı toplumsal ve psikolojik sorunları ortaya çıkmıştır. Gerçek hayatta veya dizi ve filmlerde, hatta Fi web dizisinde görüldüğü gibi teknoloji her tarafi çepeçevre sarmış ve bağımsızlığını ilan etmiştir. Günümüzde kullanılan bu cihazlar olayların seyrini değiştirerek ya yönlendirmelere maruz kalmış ya da özgür yörüngesine girerek sonuçlara sebep olmaktadır. Bugün teknoloji büyük oranda insan hayatının belirleyiciliğinde büyük rol oynamaktadır. Bu yüzden bilim ve teknoloji bugün bu sebeplerden dolayı yargılanmaktadır. McLuhan'nın söylemleri de olay1 özetlemektedir. Ona göre; "Biz ilk basta aletlerimize sekil veririz ve daba sonra aletlerimiz biže şekil verir". Bugün insan eliyle yaratılan aletlerin insan hayatına şekil verdiği görülmektedir.

Fakat tüm bu gelişmelerin sorumlusu tek bir bilim adamı ya da tek bir insan değildir. Bu yüzden toplum teknolojinin bu seyrine göre önlemler almalıdır. Teknolojik gelişmeler, icat edilen aletler, tamamen insan yararına programlanmalıdır. Teknoloji bilinçli olarak yönlendirilmelidir. Bu bağlamda bugün kendi zekası ile ortaya çıkardığı kuvvetler tarafindan tehdit edilen insanlık, bu duruma karşı çözüm yolları bulmalıdir.

Teknolojik cihazları icat eden insanların yanı sıra pazarlanmasının yapıldığı kitle iletişim araçlarına Özellikle diziler aracılı̆̆ıyla verilen reklamlara bireyler, eleştirel yaklaşmalıdır. Bu içerikleri akıllı ve etkili bir bakış açısıyla izlemelidirler. Medya kanalları hakkında bilgi sahibi olmalı, ticari yapıları ve idari şekilleri hakkında bilgi edinmelidirler. Medyanın bu ürünleri pazarlarken toplum üzerinde nasıl büyük bir etki elde edebileceklerinin bilincinde olmalıdırlar. Gerçek dünya ile medyada verilen dünya arasındaki ayrımı yapabilmelidirler. Bilinçli bir birey olup birer medya okuryazarı olmalıdırlar. Ayrıca devlet bununla alakalı kamu spotları oluşturabilmeli ve reklamların azaltılması için çalışmalar yapmalıdır.

Özellikle web dizilerini bağımlılık derecesinde takip eden bireyler, vakitlerinin çoğunu dizilerin başında geçirmek yerine kitap okumayı, tiyatroya ve sinemaya giderek sosyalleşebileceği aktiviteler tercih ederek dizi izleme sıkliklarını azaltabilmelidir. Teknolojik cihazların küçülmesi ve telefondan her şeyin yapılabilmesi her yerde kullanılabilmesini hem iyi yönde etkilemiş hem de kötü yönde etkilemiştir. Bu bağlamda bireyler bu cihazları yatak odalarına götürmemeli ortak alanlarda bu cihazları kullanmalıdırlar. Eğer bağımlılık dereceleri çok yüksek ise konu ile ilgili rehabilitasyon merkezlerine başvurarak bu sorunu çözmelidirler. 


\section{Etik Beyan}

“Teknolojik Determinizm Cerçevesinde Türkiye'de Web Dizilerinin Toplumsal Dönüsüme Etkileri: Fi Dižisi Örneğ̈” başlıklı çalışmanın yazım sürecinde bilimsel, etik ve alıntı kurallarına uyulmuş; toplanan veriler üzerinde herhangi bir tahrifat yapılmamış ve bu çalışma herhangi başka bir akademik yayın ortamına değerlendirme için gönderilmemiştir.

\section{Kaynakça}

Açıkders, “Teknolojinin Sosyal İnşası”, www.acikders.org, Erişim Tarihi: 18.04.2019.

Akgül, D. (2013). Dizi ve filmlerde ürün yerleştirmeye tüketicinin bakışı. Researchgate, 593-594.

Aktaş, C. (2007). Yeni medya ile geleneksel medyanın karşılaştırılması. Medya Üz̧erine Calışmalar (Der: G. Erol). İstanbul: Beta Yayınları.

Alpar, D., Batdal, G. ve Avc1, Y. (2007). Öğrenci merkezli eğitimde eğitim teknolojileri uygulamaları. Hasan Ali Yücel Eğitim Fakültesi Dergisi, 7, 22-23.

Altay, D. (2005). Kürsel köyün medyatik mimar1: Marshall Mcluhan. Kadife karanlık (Düz: D. Altay) (2. Bask1). İstanbul: Su Yayınevi.

Altun, F. (2003). Teknolojik determinizm ve bir muhalefet imkanı olarak internet. Researchgate, 8.

Atabek, Ü. (2001). İletişim ve teknoloji (1. Baskı). Ankara: Seçkin Yayıncilık.

Aydın, O. Ş. (2017). Yeni medya, yeni televizyon: kollektif izlemenin sonu mu? 1. Uluslararası İletişimde Yeni Yönelimler Konferansi, 430.

Aydoğan, F. (2005). Medya ve tüketim kültürü üzerine elestirel bir analiæ. (1. Bask1). İstanbul: Türkmen Kitapevi.

Bereket, Ö. (2018). Yöndeşen medya ve dijital emek sömürüsü. Panaroma Dergisi, 28, 21-22.

Çakır. M. (2017). Sosyal medya ve gösteri. Marmara Üniversitesi İletișim Fakülttesi Hakemli Dergi, 11, 2

Çelik, H. C. (2007). Heisenberg nedensellik ve determinizm. Flsf Dergisi, 4, 129.

Doğan, C. ve Özdemir Ö. (2017). Ürün yerleştirme uygulamalarının incelenmesi ve sinema sektörü ile bir örnek değerlendirme. Social Sciences Studies Journal, 1162-1165.

Duverger, M. (1973). Sosyal bilimlere giris (Çev: Ü. Oskay) (1. Baskı). Ankara: Bilgi Basım

Elden, M. ve Bakır, U. (2010). Reklam çekicilikeleri (1. Baskı) İstanbul: İletişim Yayınları.

Erdoğan, İ. ve Alemdar, K. (2010). Öteki kuram (3. Bask1). İstanbul: Erk Yayınevi.

Fakiryazar, "Web Dizileri” https://www.fakiryazar.com, Erişim Tarihi, 29.04.2018.

Giannantoni, D. (2015). Netflix: TV series during the web 2.0 era. Academia, 4.

Goodreads, "Marshall Mcluhan”, https://www.goodreads.com, Erişim Tarihi, 23.09.2018.

Güven, S. K. (2008). Yeni dünya düzeni içinde enformasyon teknolojilerinin vaatleri ve tehditleri. İstanbul Üniversitesi Iletișim Fakültesi Dergisi, 72.

Güz, N. (2012). Teknolojik gelişmeler ve haberde etik sorunlar. II. Uluslararası İletişim Sempoşymu, Kırgızistan-Türkiye Manas Üniversitesi, Bişkek, 16.

İlhan, E. ve Aydoğdu, E. (2015). Medya okuryazarlığı dersi ve yeni medya algısına etkisi. Erciyes İletişim Dergisi Akademia, 4(1), 58.

İşler Büyükler, D. (2014). televizyon reklamlarında ünlü kişilerin kullanılmasının satın alma davranışlarına etkisi: Cinsiyet ekseninde bir inceleme. Süleyman Demirel Üniversitesi Viæyoner Dergisi, 5(11), 111.

Kabakçı, I. ve Odabașı H. F. (2004). Teknolojiyi kullanmak ve teknogerçekçi olabilmek. Sosyal Bilimler Dergisi, 1, 21.

Kara, S. (2017). Teknoloji ve toplumsal değişim ilişkisinin sosyal inşa kuramı bağlamında incelenmesi. Reserchgate, 120125.

Kırık, A.M. (2010). Etkileșimli televiazyon. Ed. Levent Eldeniz, 1.Baskı, Ankara: Anahtar Kitaplar Yayın Evi.

Klein, T. (2014). Web series-between commercialand non-profit seriality, media economies. Ed. Marcel Hartwig, Evelyne Keitel, Gunter Süß, Düsseldorf: WVT Wissenschaftlicher Verlag Trier, 15. 1-5

Mcluhan, M. ve Fiore, Q. (2005). Yaradanımız medya, the medium is the massage (Çev. Ü. Oskay) (1. Bask1). İstanbul: Merkez Kitapçıllk Yayıncılık.

Milliyet, "Web Dizileri”" http://blog.milliyet.com.tr, Erişim Tarihi: 02.05.2018.

Milliyet, "Web Dizileri” http://www.milliyet.com.tr, Erişim Tarihi: 29.04.2018.

Oğuzcan, A. U. ve Hajiyev F. (2018). Dijital dizilerde ürün yerleştirme: Fi/Çi dizisi örneği. Uluslararası Illetişimde Yeni Yönelimler Konferansi, 205-206.

Özsarı, S. H., Hoşgör, H. ve Gündüz Hoşgör, D. (2016). Hastane web site performanslarının halkla ilişkiler ve tanıtım açısından incelenmesi: Türkiye, Hindistan ve İrlanda örnekleri. Researchgate, 211-212.

Puhutv, "Fi Dizisi Bölümleri” Https://Puhutv.Com, Erişim Tarihi, 21.12.2018.

Puhutv, "Fi Dizisi İzlenme Oranları” Http://M.Haber7.Com/, Erişim Tarihi, 18.04.2019.

Stratejik Araştırma Merkezi, “Değişim” Http://Sahipkiran.Org, Erişim Tarihi, 17.04.2019.

Taslaman, C. (2011). Tanrı-evren ilişkisi açısından determinizm, indeterminizm ve kuantum teorisi. Academia, 4.

Turan, S. ve Esenoğlu, C. (2006). Bir meşrulaştırma aracı olarak bilişim ve kitle iletişim teknolojileri: Eleştirel bir bakış. Osmangą̧i Üniversitesi İ̈BF Dergisi, Ekim, 72-73.

Uludağ, Z. (1993). Determinizm ve zorunsuzluk. Ondokuz Mayıs Üniversitesi Eğitim Fakültesi Dergisi, 1, 257. 
Uzunoğlu, S. (2015). Yeni medyada dijital emek sömürüsü: tüketiciden ürketiciye yeni medya: Yeni sömürü pratikleri. E-Journal Of Intermedia, 187.

Yıldırım, A. ve Şimşek, H. (2005). Sosyal bilimlerde nitel Araştırma Yöntemleri (5. Baskı). Ankara: Seçkin Yayıncılık.

\section{EXTENDED ABSTRACT}

Today, it is described as the age of communication and information. Although both concepts survive today, they have not yet reached the desired level. One of the greatest aspirations of humanity for a long time is to move to the age of information completely. The technological developments brought about by the information age have caused a change in the way of communication. In this context, face to face communication has weakened. People have begun to devote most of their time to technological devices. Undoubtedly, the benefits of technological developments are numerous, but it is an issue that should not be underestimated. Today, humanity is fully committed to technological developments. It is possible that robotics and artificial intelligence studies developed with Web 3.0 can turn into potential threats for humanity. In this context, technological developments are advancing irrevocably. Mcluhan's statement summarizes the sutiation. "One thing about which fish know exactly nothing is water, since they have no anti-environment which would enable them to perceive the element they live in."

The first original web series of PuhuTV, Fi, Azra Kohen's Fi-Çi books have been scripted. The series was shot in a drama and romantic with a professional staff. Fi web series is one of the web series that is used by the viewers who are bored with the length of television series, the uniformity of subjects, and the excessive application of censorship. In the Fi web series, the scenario follows a clever psychologist, Can Manay, whose past is full of crimes. This character presents a program on television. In the live broadcast, by giving therapy to famous people, they open their private lives to everyone and receive ratings. This character, portrays by Ozan Güven, describes someone who is very rich and has psychological problems.

The concepts of technological determinism which are the theory of the study are as follows. According to Heidegger, technology means that all tools, machines and devices manufactured and used meet the needs of the humanity. All these devices in use are technological products and at the same time technology is also a device. On the other hand, determinism is the formation of the necessary conditions for the determination of an event. In the philosophical sense, it means that the events in the world and especially the human events are related to each other in the position that the previous events determine the next events. In a universe with determinism, everything is in a cause-effect relationship.

After technology and determinism concepts come together, technological determinism has emerged. According to Mcluhan, the concept of technological determinism shapes humanity. In other words, culture is shaped at the point of communication. Today, communication technology, which has made significant progress, is the carrier of culture. Therefore, as communication technology changes, culture also changes in parallel. As a result, human life is subject to change and transformation. Marshall McLuhan explains this concept as follows: "We become what we behold. We shape our tools and then our tools shape us". The phenomenon of technological determinism makes sense to what is happening today and before. According to him, this concept cannot predict the future. Therefore, it is not possible for this theory to be tested. In this concept content is not important but the tool is important. After McLuhan, also this issue has been highly discussed. In this context, this idea is regarded as positive (optimistic) and negative (pessimistic). The optimists argue that technology is a dream and it makes life easier and effects it positively. Pessimists see technology as a totalitarian nightmare. This idea emphasizes the harmful aspects of technology. But in both perspectives, it emphasizes the determinant of technology. there is also the concept of social construction of technology. The basic idea is that reality is socially constructed and that this process of construction should fall within the sphere of sociology of science. In other words, social reality comes from institutions and structures that exist through human behavior and attitudes.

The high number of technological elements in the Fi web series constituting the sample of the study brings the theory of technological determinism to mind. The last 5 (8. 9. 10. 11. 12.) episodes of the first season of the series are analyzed with content analysis method. In the series, Can Manay follows Duru Durulay with hidden cameras. Can Manay, who attacks the private life, attacks the personal life through cameras and computers created by technological developments. Processing of such events in the content of series and movies causes the normalization of events. Indeed, similar events are experienced in real life. some examples, from time to time they are reflected in the media. This situation is the following. cameras uses for good events, but also uses for bad sitiation. This situation brings to mind the concept of 
technological determinism. In this context, is technology used for good or abuse? In addition, in some scenes, passwords of security systems are cracked. technology is abused in these examples. Many technological devices in the series are often shown. some machines and electronic devices are used to make life easier. In this respect, technology makes life easier. In this context, today technology plays an important role in determining human life. For this reason, science and technology are blamed today for these reasons. However, not a single scientist is responsible for these developments. Therefore, society should take precautions according to this course of technology. Technological advances, invented devices must be programmed entirely for human benefit. Technology should be guided consciously. 